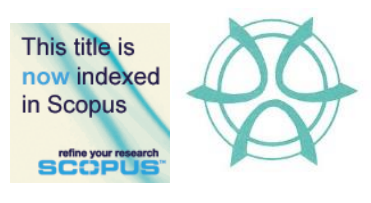

PLANNING MALAYSIA:

Journal of the Malaysian Institute of Planners

VOLUME 16 ISSUE 1 (2018), Page 348 - 359

\title{
DETERMINING MODEL CONFIGURATION FOR THERMAL SIMULATION OF URBAN MOSQUE FAÇADE DESIGN
}

\author{
Noor Hanita Abdul Majid ${ }^{1}$, Fauziah Hanum Abdullah ${ }^{2}$ \& Zuraini Denan ${ }^{3}$ \\ ${ }^{1,2,3}$ Kulliyyah of Architecture and Environmental Design \\ INTERNATIONAL ISLAMIC UNIVERSITY MALAYSIA
}

\begin{abstract}
Urban mosque (UM) façade design, besides its aesthetical role, is a passive architectural design strategy in handling how much heat penetrates into the internal spaces. In determining the model configuration for thermal simulation of urban mosque façade, the orientation and massing of the UM is tested. The orientation of UM relates to the qiblat direction and sun exposure. On the other hand, the massing is defined by the volume of the UM. This research investigates the effects of form layout and volume on thermal performance of the interior environment. A model with no openings on north-westward façade (NWF) and south-eastward façade (SEF) is simulated for a baseline scenario for comparison purposes. Autodesk Ecotect Analysis 2011 is a computer-based simulation tool used in this research to measure the thermal analysis in the UM model. The results indicate the performance of different types of forms, layouts and volumes. By the end of this study, the configuration of the base model is determined according to the results of the orientation and volume variations.
\end{abstract}

Keyword: urban mosque, baseline model, thermal simulation, form layout and volume 
PLANNING MALAYSIA

Journal of the Malaysia Institute of Planners (2018)

\section{INTRODUCTION}

Urban microclimate of Kuala Lumpur is characterised by high temperatures and humidity with low wind velocity. This condition is in accordance to the observation by Marzita, Mohd Hairy, Mazlini, Che Nidzam and Noraini (2012) that confirmed the increased temperature at urban built-up areas compared to urban fringes and rural areas. Jusuf, Wong, Hagen, Anggoro and Hong (2007) suggested that the gradual rise in urban air temperature in all cities in the world are caused by drastic reduction of the green area. The high temperature in urban areas lead to concerns in attaining indoor thermal comfort with the threat of climate change (Adunola, 2012). Hence in the urban microclimate is a major concern in offering comfortable indoor environment. Mosques in urban area are subjected to the high temperature conditions in urban microclimate that lead to uncomfortable thermal condition for the worshippers to perform prayers.

Congregational prayer times are the critical periods due to high number of people in the prayer hall area. The alternative to maintain a thermally comfortable conditions is using air conditioning to cool the interior space. Dependence on air conditioning system to cool the main prayer hall increased the energy consumption and electricity cost which will burden the management of the mosque. Therefore, it is important for the urban mosque to adopt passive design strategies that will in turn sustain a conducive interior environment of the urban mosque.

Building design have a primary function to provide an internal environment that is suitable for the purpose of the building (Department of Standards Malaysia, 2014a). Façade design is a passive design strategy in response to the climatic context of the urban area. A suitable façade design optimise daylighting and thermal comfort (Department of Standards Malaysia, 2014b) of the interior spaces. Shafizal (2014) found that big openings allow the heating and cooling process faster as the indoor air temperature reaches the same temperature with the outside air. Consequently, the open areas of the building façade have an influence on the heat gain of the indoor environment. Hence, it is important to focus on the façade design over the aesthetic expression, as a reliable passive design strategy contributes to thermal comfort of the indoor environment.

The issues discussed highlight issues on the urban mosque thermal comfort and how façade design is important to control the thermal comfort of the interiors. This research intends to determine the model configuration for thermal simulation of urban mosque façade design. The model is important to test the performance of the façade design for urban mosque.

\section{RESEARCH OBJECTIVES}

Questions arisen from the previous findings; What are the critical façade orientations? What is the performance of urban mosque facades? What are the effects of form, layout and volume to thermal comfort? This research will 
Noor Hanita Abdul Majid, Fauziah Hanum Abdullah \& Zuraini Denan

Determining Model Configuration for Thermal Simulation of Urban Mosque Façade Design

determine the critical façade orientation (form and layout) and the effects of massing (volume) on thermal performance of the interior environment.

\section{Façade Orientations}

The façade orientations are related to direct sun penetration into buildings which consequently affects thermal comfort of the indoor environment. Most researchers such as Liping and Hien (2006), Al-Obaidi and Woods (2006), AlTamimi and Sharifah Fairuz (2011), and Al-Tamimi, Sharifah Fairuz and Wan Mariah (2011) suggest that maximising façade orientation towards North and South resulted to better indoor thermal environment compared to east and west orientations. In the case of urban mosque, the building is orientated directly towards Qiblat (the direction towards the Holy Kaabah in the city of Makkah). This orientation is a must rather than being a design variable (Al-Homoud, 1999).

The mosque façade orientations can be deemed as North-westward façade (NWF) or qiblat-façade-facing, South-westward façade (SWF), North-eastward façade (NEF) and South-eastward façade (SEF) (Figure 1). The mosque superimposed on a sun path diagram of Kuala Lumpur (see Figure 2) indicates that the NWF and SEF are the facades facing towards direct sun path that consequently affects the indoor thermal condition of the mosque. Hence, the northwest and southeast façades need to be incorporated in the passive design strategies to handle the unwanted exposure to direct sunlight.

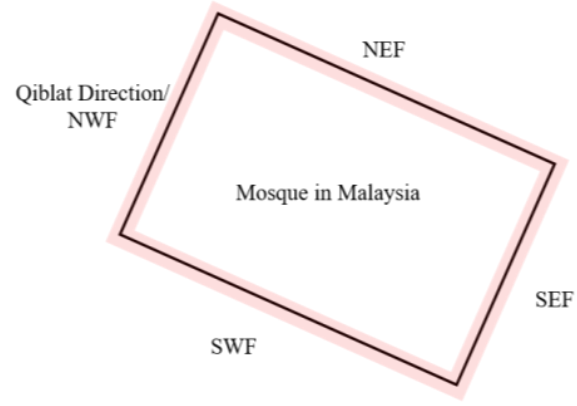

Figure 1: Mosque facade orientations

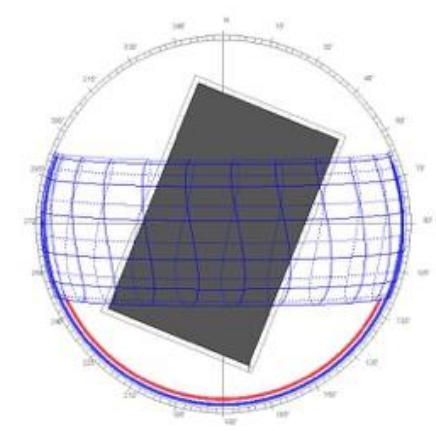

Figure 2: Sun path diagram of mosque façade orientation

\section{RESEARCH METHODOLOGY}

This research is focused on developing a model for thermal simulation to determine the urban mosque façade design for the thermal comfort of the indoor environment. The baseline model will be used for further indoor thermal simulation models of variety façade designs. The model is tested on factors such as façade orientation and massing. The significance and impact of design 
parameters depend on the essential characteristics of the input and output variables such as building volume, type of layout form and so forth for further simulations of other UM façade design models. Autodesk Ecotect Analysis 2011 software is used to test the baseline model and the design variables.

\section{Baseline Model: Urban Mosque Model Configurations}

The baseline model for the computational experiment is the configuration to be developed and utilized to test the different façade design variables. A basic UM model with no opening on North-westward façade (NWF) and South-eastward façade (SEF) is proposed as baseline model. All the input required by Ecotect to simulate thermal comfort such as, building system, internal design consideration, activity level, materials and properties and are as described in Table 1.

Table 1: Urban mosque model configurations

\begin{tabular}{|c|c|c|c|}
\hline No. & Characteristics & \multicolumn{2}{|l|}{ Descriptions } \\
\hline 1 & Façade Openings & \multicolumn{2}{|c|}{ NWF \& SEF: no opening } \\
\hline & & \multicolumn{2}{|c|}{ NEF \& SWF: $10 \%$ opening area each } \\
\hline 2 & Dimension & \multicolumn{2}{|c|}{$25 \mathrm{~m}$ x 40m (Type A) and 40m x 25m (Type B) } \\
\hline 3 & Occupancy & \multicolumn{2}{|c|}{$\begin{array}{l}1000 \text { occupant (full capacities) and } 10 \% \text { from full } \\
\text { capacities (100) }\end{array}$} \\
\hline 4 & Form Layout & \multicolumn{2}{|c|}{ Rectangular Type A and Type B (see figure 3 ) } \\
\hline 5 & Volume & \multicolumn{2}{|c|}{ Single, Double and Triple (see figure 4) } \\
\hline 6 & Site Location & \multicolumn{2}{|c|}{ Kuala Lumpur, $3.1 \mathrm{~N}$ and 101.6 E } \\
\hline 7 & Local Terrain & \multicolumn{2}{|l|}{ Urban } \\
\hline \multirow[t]{4}{*}{8} & $\begin{array}{l}\text { Internal Design } \\
\text { Condition }\end{array}$ & 1. Clo. Value, clo. & $\begin{array}{l}\text { :0.89 adopted from (Hussin, } \\
\text { Salleh, Chan, and Mat, 2014) }\end{array}$ \\
\hline & & 2. Humidity, $\%$ & $\begin{array}{l}: 70 \% \text { as recommended by } \\
\text { MS1525:2014 }\end{array}$ \\
\hline & & $\begin{array}{l}\text { 3. Air Movement, } \\
\mathrm{m} / \mathrm{s}\end{array}$ & $\begin{array}{l}: 0.5 \text { as recommended by } \\
\text { MS1525:2014 }\end{array}$ \\
\hline & & $\begin{array}{l}\text { 4. Lighting Value, } \\
\text { lux }\end{array}$ & $\begin{array}{l}: 300 \text { as recommended by ISO } \\
8995(2002) \text { and SASO (2009) }\end{array}$ \\
\hline 9 & Activity Level & \multicolumn{2}{|c|}{ 70W at Sedentary Level } \\
\hline 10 & Building System & \multicolumn{2}{|l|}{ Naturally Ventilated } \\
\hline 11 & Comfort Band & \multicolumn{2}{|c|}{$24^{\circ} \mathrm{C}-26^{\circ} \mathrm{C}$ as recommended by MS1525:2014 } \\
\hline \multirow[t]{2}{*}{12} & $\begin{array}{l}\text { Materials and } \\
\text { Properties }\end{array}$ & 1. Wall & $\begin{array}{l}130 \mathrm{~mm} \text { brick with } 10 \mathrm{~mm} \text { plaster } \\
\text { either side }\end{array}$ \\
\hline & & 2. Floor & $\begin{array}{l}100 \mathrm{~mm} \text { thick concrete slab on } \\
\text { ground plus ceramic tiles. }\end{array}$ \\
\hline
\end{tabular}


Noor Hanita Abdul Majid, Fauziah Hanum Abdullah \& Zuraini Denan

Determining Model Configuration for Thermal Simulation of Urban Mosque Façade Design

3. Ceiling

$150 \mathrm{~mm}$ THK Concrete with both side each $12 \mathrm{~mm}$ THK ceramic tiles and gypsum. The air gap is $600 \mathrm{~mm}$ between concrete and gypsum

13 Measurement Hottest Day-6 July as recommended by EnergyPlus Period Weather Data of Kuala Lumpur

The model represents a rectangular building with a plan size of $1000 \mathrm{~m}^{2}$ within the dimension of $25 \mathrm{~m} \times 40 \mathrm{~m}$ or $40 \mathrm{~m} \times 25 \mathrm{~m}$. The $1000 \mathrm{~m}^{2}$ is decided based on 1000 persons with $1 \mathrm{~m}^{2}$ is allocated per person occupancy as recommended by MS2577:2014 (Department of Standards Malaysia, 2014b). However, as seen in Figure 3, the rectangular form can be orientated into two types of form layout (type A and Type B). The investigation discussed in this research focus on the façade opening on NWF and SEF, while the opening on North-eastward façade (NEF) and South-westward façade (SWF) is controlled with $25 \mathrm{~m}^{2}$ opening at each (as shown in figure 4). The orientation of the model is referring to the orientation of mosque building which is orientated towards qiblat direction $\left(232^{\circ}\right)$. The solar charts used are for Kuala Lumpur. The exposure to direct solar need to be minimized by having shorter facades towards NWF and SEF.

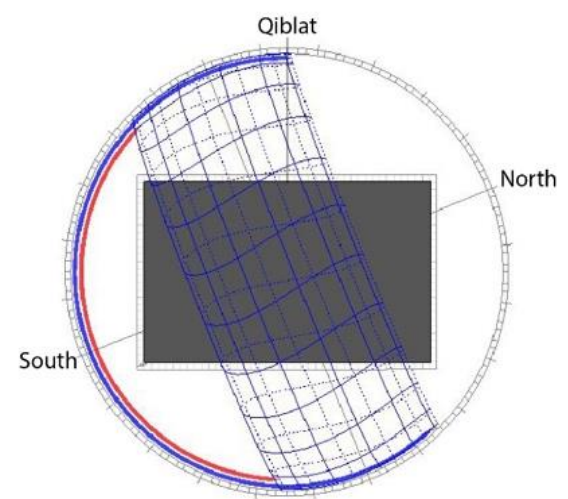

Type A

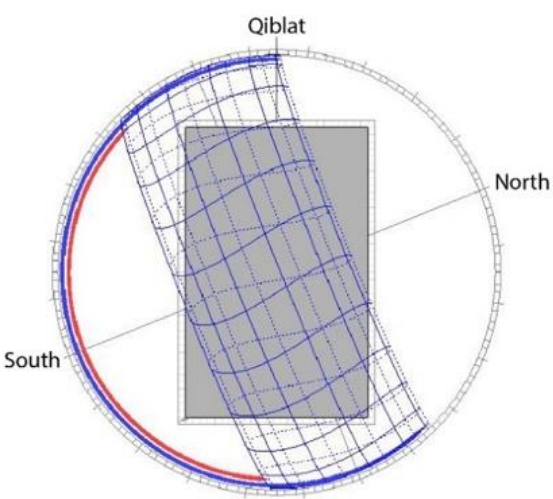

Type B

Figure 3: Form layout Type A and Type B

*Inventory conducted on UM in Kuala Lumpur City has identified a total of 56 urban mosques. These samples are categorized into three groups; single volume (4-6 metres high), double volume (7-9 metres high) and triple volume (10-13 metres high) where the height for each groups is shown in Figure 4. 
PLANNING MALAYSIA

Journal of the Malaysia Institute of Planners (2018)

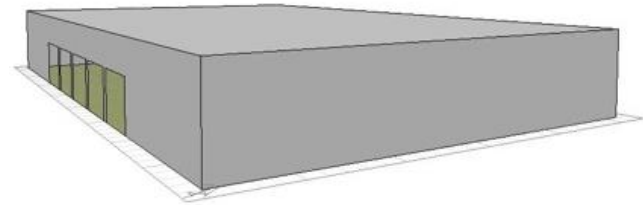

Single

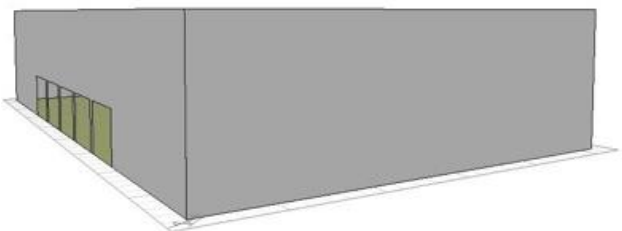

Double

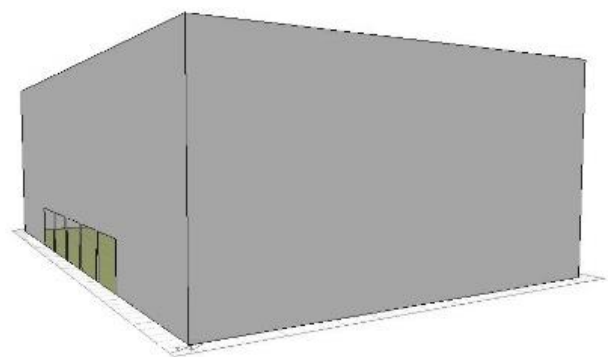

Triple

Figure 4: Types of volumes for UM

The building is planned to be occupied by 100 persons for normal prayer times (subuh, asar, maghrib and isya') and 1,000 occupants (for Friday prayers) for comparison on effect of number of occupancy on thermal comfort.

\section{Autodesk Ecotect Analysis 2011}

The measurement of thermal comfort is done by using the methods of simulation with Autodesk Ecotect Analysis 2011 software. This research chooses to use Ecotect program because of its facilities with respect to making a perfect induction on thermal performance of the building and pleasant user interface, which is easily used by architects (Crawley, Hand, Kummert, \& Griffith, 2008). The thermal measurement calculation suggested by Ecotect for a building model without using air conditioning system is temperature, loss and gain, and comfort. Measuring temperature is the focus of this research to analyse indoor thermal comfort. The calculations related to measuring temperature in Ecotect is Hourly temperature (HT) and Annual Temperature Distribution (ATD). Thus, these two calculations will be applied and analysed to discuss thermal comfort in UM. 
Noor Hanita Abdul Majid, Fauziah Hanum Abdullah \& Zuraini Denan

Determining Model Configuration for Thermal Simulation of Urban Mosque Façade Design

\section{Weather Data}

For the purpose of this research, the weather data of Kuala Lumpur is obtained from EnergyPlus website (EnergyPlus, 2016) and converted to suitable file format for Ecotect. The site location and local terrain is set up respectively to Kuala Lumpur as the selected location for urban mosque in this research. The thermal analysis is experimented on the hottest day of the year or $6^{\text {th }}$ July for hourly temperature thermal calculation.

\section{Data Analysis}

The result of thermal comfort simulation on baseline model will be analysed in three stages;

i. First Stage: Relationship between thermal analysis with Type of Form layout.

ii. Second Stage: Relationship between thermal analysis with Type of Volume.

iii. Third Stage: Thermal analysis of UM Baseline Model

The result will justify model configurations of further UM model simulations on thermal comfort.

\section{RESEARCH ANALYSIS AND FINDINGS}

At the first stage, a baseline model of UM with form layout type B was analysed. Second, the result of different types of volume was investigated. The results determined the final model configurations of UM which would be utilized for further investigation on thermal comfort.

\section{Effect of Form Layout}

There was minimal difference in indoor temperature for Type A and Type B (see Figure 5). During prayers times, both layout was not comfortable for worshippers. The highest temperature recorded was $35.5^{\circ} \mathrm{C}$ and $35.6^{\circ} \mathrm{C}$ during Friday prayer by both types of Layout. However, for annual temperature distribution (ATD) analysis, Type B recorded slightly higher comfort temperature percentage than Type A, where the comfort temperature percentage over the year (see Table 2) was $+0.3 \%$. Hence, the form layout of UM had significant in providing thermal comfort in UM. Both type of layout form of UM recorded uncomfortable conditions based on recommended comfort range by MS1525:2014 (Department of Standards Malaysia, 2014a). 


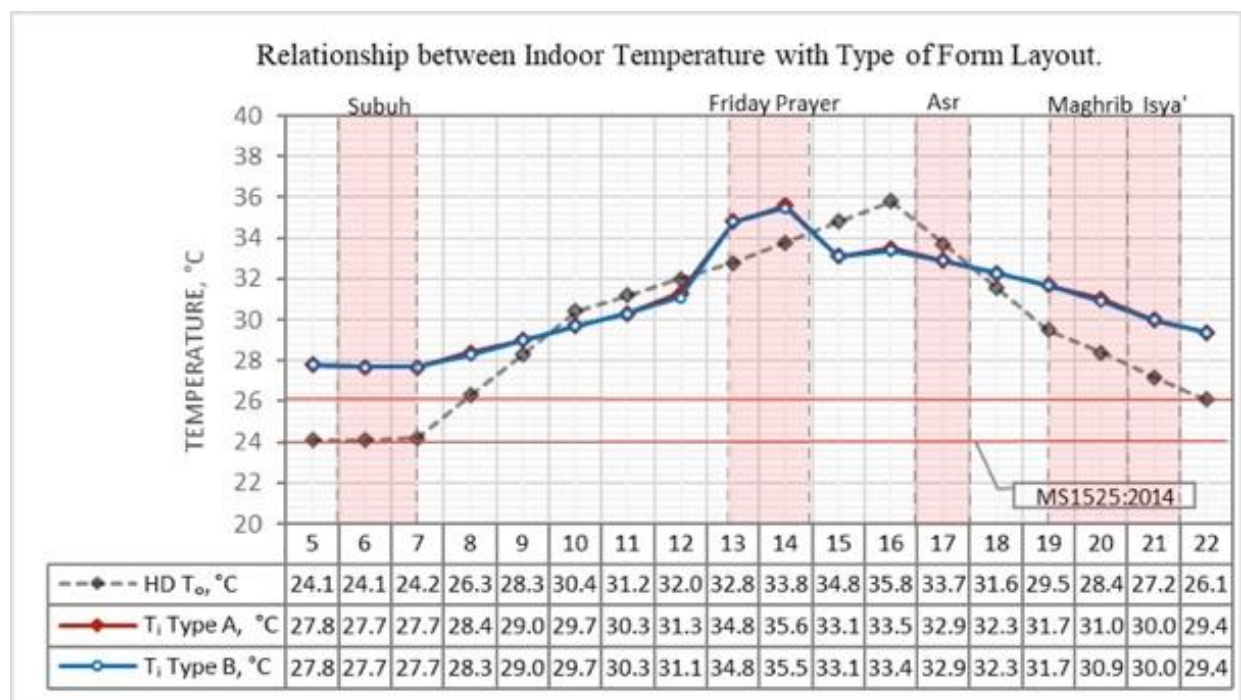

Figure 5: Relationship between hourly temperature with type of UM layout during hottest day (peak)

Table 2: Relationship between annual temperature distribution with type of UM layout

\begin{tabular}{l|c}
\hline Type of Form Layout UM & $\begin{array}{c}\text { Comfort Temperature, \% (as recommended by } \\
\text { MS1525:2014) }\end{array}$ \\
\hline Type A, 25m x 40m & 37.7 \\
Type B, 40m x 25m & 38.0 \\
\hline
\end{tabular}

\section{Effect of Volume}

The graph of relationship between indoor temperature with types of volume of UM is presented in Figure 6. Single volume recorded higher indoor temperature compared to double and triple volume. Triple volume documented better indoor temperature than single and double volume. During 1000-1100h, Triple volume and double volume registered lower indoor temperature than outdoor temperature. While around 1500-1700h, all type of volumes displayed lower indoor temperature than outdoor. However, all types of volume were beyond the recommended comfort range by MS1525:2014. The results suggested that the occupants never feel comfort during all five time daily prayers including during Friday prayer. 
Noor Hanita Abdul Majid, Fauziah Hanum Abdullah \& Zuraini Denan

Determining Model Configuration for Thermal Simulation of Urban Mosque Façade Design

Table 3: Relationship between annual temperature distribution with type of UM volume

\begin{tabular}{ll}
\hline Type of Volume & $\begin{array}{l}\text { Comfort Temperature,\% (as recommended by } \\
\text { MS1525:2014) }\end{array}$ \\
\hline Single & 15.3 \\
Double & 27.0 \\
Triple & 38.0 \\
\hline
\end{tabular}

As recommended by MS1525:2014, triple volume recorded highest comfort temperature percentage along the year compared to double volume and single volume registered the lowest comfort percentage (see Table 3). Through the results of 2 series of investigation on thermal comfort based on hourly temperature and annual temperature distribution, the triple volume UM was selected for further investigation on effect of façade design.

Relationship between Indoor Temperature with Type of Volume

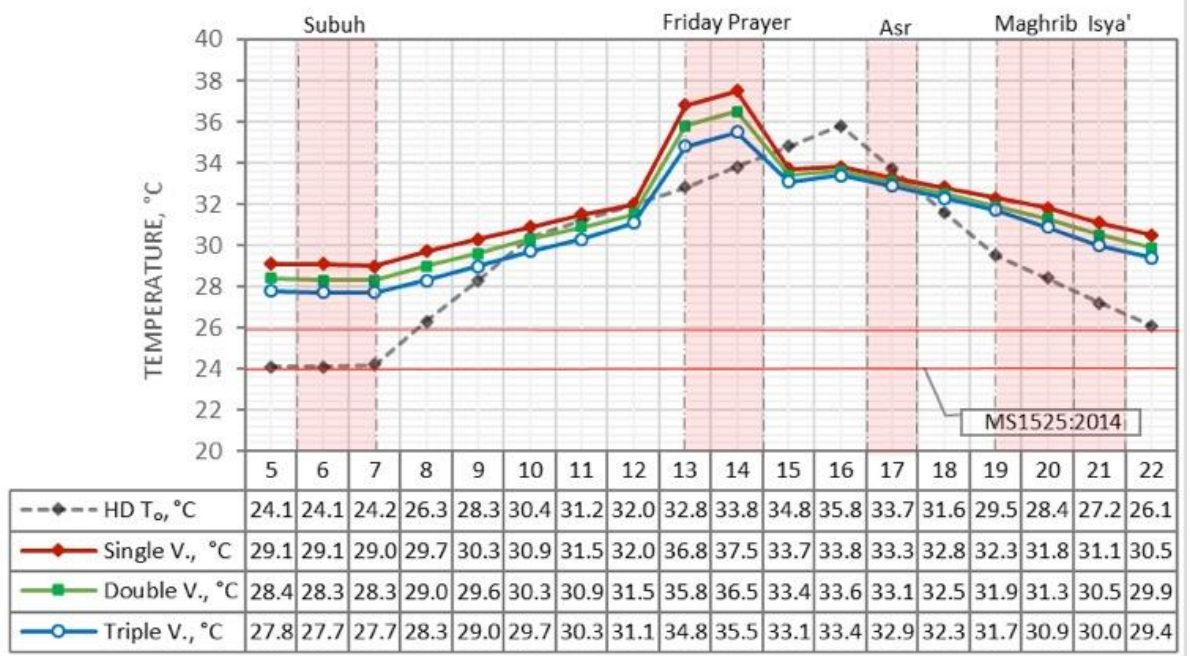

Figure 6: Relationship between hourly temperature with type of um volume during hottest day (peak)

\section{CONCLUSION}

Determining the procedure for simulation of thermal comfort through baseline model provided the preliminary data to further investigate thermal comfort performance of the other UM Models. Although the determination of thermal comfort through baseline model is a preliminary study, it is an essential phase to be able to compare and refer for further simulations. The following results are the determining factor for the baseline model; 
PLANNING MALAYSIA

Journal of the Malaysia Institute of Planners (2018)

1. The triple volume obtained better percentage for thermal comfort conditions compare to double and single volume.

2. The number of occupancies played significant role in indoor thermal condition. The highest number of occupancy increased the level of discomfort. However, the mosque was dealing with intermittent occupancies where the number of occupant was irregular. Therefore, for the purpose of research, occupancy schedule was proposed at $10 \%$ occupancy for congregational prayers except during Friday prayer (1300$1430 \mathrm{~h})$ and zuhur prayer time that was simulated for full capacity $(1,000$ persons).

3. The type B (rectangular form with the short façade facing qiblat or Northwestward façade (NWF)) recorded better thermal condition. This indicate the small surface of façade would gain low heat than large surface.

4. All result was mapped against the recommended comfort range by MS1525:2014. The baseline showed that the temperature was beyond the recommended comfort range.

Through the investigation on type of form, layout and volume, the configuration of UM baseline model is type B layout form with triple volume is the selected model. All other parameters in Table 1 is maintained to further investigate on the effect of different façade design for the UM. For future recommendation, investigating UM with effects of different air velocity may improve the comfort conditions or the performance of ATD. Further research on the UM is important to underline the basic urban mosque façade design that will in turn provide thermal comfort instead of merely for aesthetic values. 
Noor Hanita Abdul Majid, Fauziah Hanum Abdullah \& Zuraini Denan

Determining Model Configuration for Thermal Simulation of Urban Mosque Façade Design

\section{ACKNOWLEDGMENT}

This work was supported in part by RIGS17-096-0671. The authors would like to thank all involved in materializing this research.

\section{REFERENCES}

Adunola, A. O. (2012, April). Urban residential comfort in relation to indoor and outdoor air temperatures in Ibadan, Nigeria. In 7th Windsor Conference: The changing context of comfort in an unpredictable world Cumberland Lodge, Windsor, UK. April 12-15, 2012. Windsor, United Kingdom.

Al-Homoud, M. S. (1999). Thermal design optimization of mosques in Saudi Arabia. In Proceedings of the International Symposium on Mosque Architecture (pp. 15-30). Retrieved 31 August, 2017 from http://faculty.kfupm.edu.sa/ARE/ alhomoud/Publications/Mosque_Architecture_Symposium_99.pdf.

Al-Obaidi, M. A. A. H., \& Woods, P. (2006). Investigations on effect of the orientation on thermal comfort in terraced housing in Malaysia. International Journal of Low Carbon Technologies, 1(2), 167-176.

Al-Tamimi, N. A. M., \& Sharifah Fairuz, S. F. (2011). Thermal performance analysis for ventilated and unventilated glazed rooms in Malaysia (Comparing simulated and field data). Indoor and Built Environment, 20(5), 534-542.

Al-Tamimi, N. A. M., Sharifah Fairuz, S. F., \& Wan Mariah, W. H. (2011). The effects of orientation, ventilation, and varied WWR on the thermal performance of residential rooms in the tropics. Journal of Sustainable Development, 4(2), 142 149.

Crawley, D. B., Hand, J. W., Kummert, M., \& Griffith, B. T. (2008). Contrasting the capabilities of building energy performance simulation programs. Building and Environment, 43(4), 661-673.

Department of Standards Malaysia (2014a). MS1525:2014. Malaysia standard: Code of practice on energy efficiency and use of renewable energy for non-residential buildings (Second Revision).

Department of Standards Malaysia (2014b). MS2577:2014. Malaysian standard architecture and asset management of masjid - Code of practice.

EnergyPlus (2016). Weather data by location. All regions-Southwest Pacific WMO Region 5-Malaysia. Weather data download-Kuala Lumpur 486470 (IWEC). Retrieved August 13, 2016 from https://energyplus.net/weatherlocation/southwest_pacific_wmo_region_5/MYS//MYS_Kuala.Lumpur.486470_ IWEC

Hussin, A., Salleh, E., Chan, H. Y., \& Mat, S. (2014). Thermal comfort during daily prayer times in an air-conditioned mosque in Malaysia. Proceedings of 8th Windsor Conference: Counting the Cost of Comfort in a Changing World, (April), 10-13.

ISO 8995 (2002). International Standard ISO 8995 - Lighting of indoor work places (Second edition 2002-05-15). Geneva: International Organization for Standardization. 
Jusuf, S. K., Wong, N.H., Hagen, E., Anggoro, R., \& Hong, Y. (2007). The influence of land use on the urban heat island in Singapore. Habitat International, 31(2), 232242.

Liping, W., \& Hien, W. N. (2006, September). The impact of façade designs: Orientations, window to wall ratios and shading devices on indoor environment for naturally ventilated residential buildings in Singapore. PLEA2006 The 23rd Conference on Passive and Low Energy Architecture. September 6-8, 2006, Geneva, Switzerland.

Marzita, P., Mohd Hairy, I., Mazlini, A., Che Nidzam, C. A., \& Noraini, M. N. (2012) Thermal comfort in classroom: Constraints and issues. Procedia - Social and Behavioral Sciences, 46, 1834-1838.

SASO (2009). SAUDI STANDARD DRAFT NO: 4520. Code for Lighting of Indoor Work Places. Saudi Arabian Standards Organization (SASO).

Shafizal, M. (2014). Roof designs and affecting thermal comfort factors in a typical naturally ventilated Malaysian mosque (Doctorate dissertation). Cardiff University, Wales. 